\title{
Micro-leakage at the implant-abutment interface with different tightening torques in vitro
}

\author{
João Paulo da SILVA-NETO'; Marcel Santana PRUDENTE²; Thiago de Almeida Prado Naves CARNEIRO²; Mauro \\ Antônio de Arruda NÓBILO3; Mario Paulo Amante PENATTI4; Flávio Domingues das NEVES ${ }^{5}$
}

1- DDS, MSc, Department of Fixed Prostheses, Occlusion and Dental Materials, School of Dentistry, Federal University of Uberlândia, Uberlândia, MG, Brazil.
2- DDS Department of Fixed Prostheses, Occlusion and Dental Materials, School of Dentistry, Federal University of Uberlândia, Uberlândia, MG, Brazil.
3- DDS, MSc, PhD, Department of Prosthodontics and Periodontology, Piracicaba Dental School, University of Campinas, Campinas, SP, Brazil.
4- BDS, MSc, PhD, Technical School of Health, Federal University of Uberlândia, Uberlândia, MG, Brazil.
5 DDS, MSc, PhD, Department of Fixed Prostheses, Occlusion and Dental Materials, School of Dentistry, Federal University of Uberlândia, Uberlândia, MG, Brazil

Corresponding address: Flávio Domingues das Neves - Departamento de Oclusão, Próteses Fixas e Materiais Dentários - Faculdade de Odontologia, Universidade Federal de Uberlândia - Av. Pará, n 1720 - Umuarama - 2B - Room 2B-01 - Uberlândia - MG - Brasil - $38405-902$ - Phone \# +55 - 34 - 32182222 - e-mail: neves@triang.com.br

Received: May 16, 2012 - Modification: August 16, 2012 - Accepted: September 14, 2012

\section{ABSTRACT}

\begin{abstract}
bjectives: This study evaluated the microleakage at the implant/abutment interface of external hexagon (EH) implants and abutments with different amounts of bacteria and tightening torques. Material and Methods: A bacterial suspension was prepared to inoculate the implants. The first phase of this study used nine EH implants and abutments that were divided into three groups with different amounts of bacterial suspension $(n=3)$ : V0.5: 0.5 $\mu \mathrm{L} ; \mathrm{V} 1.0: 1.0 \mu \mathrm{L}$ e V1.5: $1.5 \mu \mathrm{L}$, and tightened to the manufacturer's recommended torque. The second phase of this experiment used 27 assemblies that were similar to those used in the first phase. These samples were inoculated with $0.5 \mu \mathrm{L}$ of bacterial suspension and divided into three groups $(n=9)$. T10: $10 \mathrm{Ncm} ;$ T20: $20 \mathrm{Ncm}$ and T32: $32 \mathrm{Ncm}$. The samples were evaluated according to the turbidity of the broth every 24 hours for 14 days, and the bacteria viability was tested after that period. The statistical evaluation was conducted by Kruskal-Wallis testing $(p<.05)$. Results: During the first phase, groups V1.0 and V1.5 was presented with bacterial contamination in all samples after $24 \mathrm{~h}$. During the second phase, two samples from group T10 and one from T20 presented positive results for bacterial contamination. Different amounts of bacterial solution led to overflow and contamination during the first $24 \mathrm{~h}$ of the experiment. The tightening torques did not statistically affect the microleakage in the assemblies. However, the group that was tightened to $32 \mathrm{Ncm}$ torque did not show any bacterial contamination. Conclusion: After 14 days of experimentation, the bacteria were proven to remain viable inside the implant internal cavity.
\end{abstract}

Key words: Dental implants. Microleakage, Dental abutments. Microbiology.

\section{INTRODUCTION}

Success in implant therapy demands a balance between biological and mechanical factors ${ }^{11}$. Failures in these procedures have been associated with a lack of stability or a misfit at the implant/ abutment (I/A) interface ${ }^{1,11,28}$. External hexagon (EH) implants ad modum Branemark present an acceptable amount of bone loss around the I/A interface. This bone loss is considered to be normal at approximately $1.0 \mathrm{~mm}$ for the first year of function and $0.2 \mathrm{~mm}$ thereafter ${ }^{1}$. The I/A interface is correlated with the presence of bacterial infiltration and inflammatory cells that can lead to bone loss around this area $5,6,15,17,27$.

The amount of bacterial infiltration between the implants and abutments depends on factors such as the fit accuracy between the pieces and the tightening torque and micro-movements between the connected components during mastication $\mathrm{n}^{7,19,24,28,30}$. Preventing bacterial infiltration at the I/A interface was a challenge that was pursued during the development of twostage implants. The goal was to minimize the 
inflammatory reaction and therefore maintain the bone around the implant top ${ }^{9,25}$. Implant companies attempt to reduce this bacterial infiltration by increasing the accuracy and stability of the jointed parts through the fabrication of mechanical pieces with a high degree of precision $9,25,26$.

The I/A interface in $\mathrm{EH}$ implants is reported as being more favorable to the infiltration of fluids than other joints ${ }^{4,10,14,16,18,23,26,29}$. The microgap in this implant design varies from 1 to $49 \mu \mathrm{m}$, depending on the type of abutment that is selected ${ }^{7,14}$. It represents a risk for plaque accumulation that favors bacterial aggregation $3,14,19-22,24,26,28,30$. In vitro studies on bacterial infiltration have used different species of bacteria with sizes that vary from 1 to 10 $\mu \mathrm{m}^{3,4,9,10,12,14,16,19-21,23,24,26,29,30}$. Toxins and stains ${ }^{4,8,13}$ from these bacteria ${ }^{14}$ have also been used and are even smaller. Escherichia coli is a facultative anaerobic bacteria that ranges from 1.1 to $1.5 \mu \mathrm{m}$ in diameter. It has great motility and has been widely used in similar implant-related studies such as this one $\mathrm{e}^{16,30}$.

Several methodologies have been used to evaluate the magnitude of this microgap at the I/A interface as well as its real influence in the bacterial infiltration process $s^{9,14,16,26,29}$. Bacterial infiltration has been evaluated in a two-way path, not only from inside the screw role to the outside $(\mathrm{I} / \mathrm{E})^{3,4,8,12-14,16,19,30}$, but also inward from the outer part of the implant $(E / I)^{4,9,10,12,20,23,26}$. The results have been evaluated through qualitative methods of turbidity of nutrient broths $4,12,14,16,19,23,24,30$ and quantitative methods of analyzing bacterial DNA $^{3,10,21}$. Nonetheless, all methods have several critical points that can either lead to false positive or false negative results. Some of these points include holding the implant with forceps; free-hand inoculation of the bacterial suspension inside the implant; sealing the entire implant by favoring fluids that flow inside the interface; using a single torquemeter for all samples; failing to determine the area inside the implant so that the right amount of bacterial suspension can be used; the type of bacteria and its viability within the study conditions and the sterile technique that is used when studying the inward flow from the outer part of the implant. This lack of standardization in the methodology leads to a large amount of variability in the results observed in these studies ${ }^{29}$.

The lack of standardized knowledge about this microgap and its influence in the bacterial colonization and proliferation makes it difficult to provide information about the flow of fluids between the inner and outer parts of the I/A interface ${ }^{8}$. The hypothesis was that not only the volume of bacteria inoculated inside the internal cavity of the implant but also the tightening torque of the abutment screw influence bacterial microleakage in non-loading conditions. Therefore, the aim of this study was to evaluate the role of different abutment tightening torques in microleakage at the $\mathrm{I} / \mathrm{A}$ interface in $\mathrm{EH}$ implants ad modum Brånemark in static conditions.

\section{MATERIAL AND METHODS}

Twenty-seven $\mathrm{EH}$ and external torque screwtype cylindrical implants $(3.75 \times 11 \mathrm{~mm})$ and conical abutments $(4.1 \mathrm{~mm}$ platform and $4.0 \mathrm{~mm}$ transmucosal height - NEODENT ${ }^{\circledR}$, Curitiba, SP, Brazil) were used in this study. During the first phase, the ideal volume of the bacterial suspension to be inoculated inside the implant was evaluated. This volume was then used in the second phase to evaluate the effect of the tightening torque (Figure 1).

Escherichia coli bacteria (ATCC 35218) was cultivated in brain heart infusion broth - BHI (Biolife, Milan, Italy) in an incubator (BIOMATIC, Porto Alegre, RS, Brazil) for $24 \mathrm{hrs}$ at $37^{\circ} \mathrm{C}$ and used in this experiment. All of the instruments that were used were autoclaved at $121^{\circ} \mathrm{C}$ at 15 psi for 15 minutes.

For the first phase, nine I/A sets were randomly inoculated with different volumes of bacterial suspension and divided into three groups $(n=3)$ : V0.5 - $0.5 \mu \mathrm{L} ; \mathrm{V} 1.0-1.0 \mu \mathrm{L}$ and V1.5 - $1.5 \mu \mathrm{L}$ (Figure 1). All of the procedures and necessary materials were conducted under clean conditions of a laminar flow hood (VECO, Campinas, Brazil). A standard bacterial suspension dilution of 0.5 McFarland ( $10^{8}$ colony forming unit/mL - CFU/ $\mathrm{mL}$ ) was prepared and taken to the hood. Microcentrifuge tubes (Eppendorf, Enfield, USA) were filled with $140 \mu \mathrm{L}$ of $\mathrm{BHI}$ by using an automatic pipette (20-200 $\mu \mathrm{L}$, LABMATE+, HT-High Tech Laboratories, PZ HTL S.A, Warsaw, Poland). The implants were set on a holder and swabbed to evaluate the sterile condition. The swabs were also kept in BHI. An automatic pipette (0.1-20 $\mu \mathrm{L}$, LABMATE+, HT-High Tech Laboratories, PZ HTL S.A, Warsaw, Poland) was fixed to the vertical shaft of a dental surveyor (BIOART, São Carlos, SP, Brazil) (Figure 2). The stabilized pipette allowed inoculating the amount that was necessary for each experimental group inside the implant internal cavity (screw channel).

After the implant, the internal cavity was inoculated, the abutment was opened and carefully installed by using sterile pliers. It was then tightened to $20 \mathrm{Ncm}$ torque, according to the manufacturer's recommendations, with a manual torquemeter that was individually calibrated for each sample. For the torque to be applied, the implant was kept in the implant holder (Figure 2E). The implant holder was manually stabilized during the torque. A new swab 


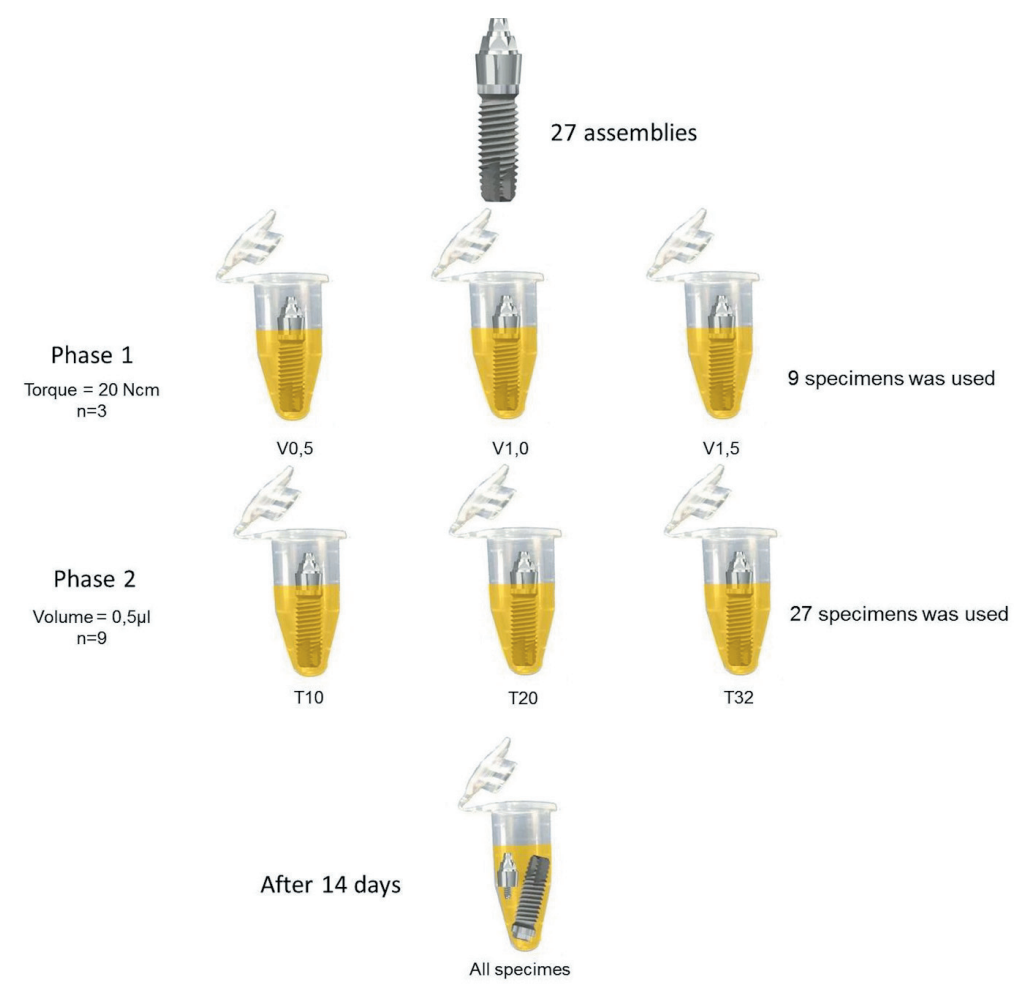

Figure 1- Study flow chart

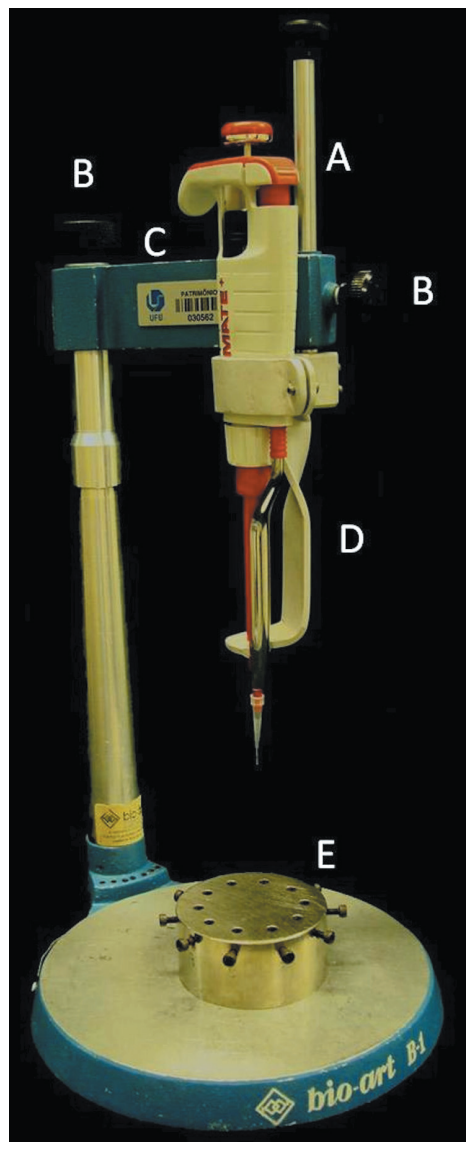

Figure 2- Inoculation device adapted from a dental surveyor. A: vertical rod with pipette holder; B: screw to lock vertical rod; C: cross arm; D: pipette holder; E: implant holder

was obtained from the I/A interface to assure that no leakage or overflow of the bacterial suspension had occurred during the abutment installation and screw tightening process. After inoculation, all of the implant/abutment samples and swabs were kept in sterile BHI broth. The tubes with implants and swabs were maintained in an incubator at $37^{\circ} \mathrm{C}$ for up to 14 days in order to evaluate the bacterial infiltration at the I/A interface.

The swabs for contamination control were evaluated after $24 \mathrm{~h}$ by changes in the broth's turbidity. A turbid broth indicated bacterial leakage during the inoculation and/or abutment installation and that sample would be excluded. The implant/ abutment samples were also evaluated every 24 $\mathrm{h}$ by the same method to evaluate the bacterial microleakage at the I/A interface.

For the second phase, the materials and I/A sets that were used in the first phase were autoclaved as previously mentioned. Twenty-seven implant/ abutment sets were randomly divided into three groups $(n=9)$. Each group received a different tightening torque: T10: $10 \mathrm{Ncm}$; T20: $20 \mathrm{Ncm}$ and T32: $32 \mathrm{Ncm}$. The amount of solution to be inoculated according to the first phase of this study was set to $0.5 \mu \mathrm{L} E$. coli solution at a $0.5 \mathrm{McF}$ arland density. The protocol for inoculation, contamination control and incubation was maintained the same as the first phase. After 14 days, if no bacterial growth was observed, the I/A samples were opened in the laminar flow hood. After both phases of this study, the disassembled components were placed in a new tube with sterile BHI to verify the viability of the 

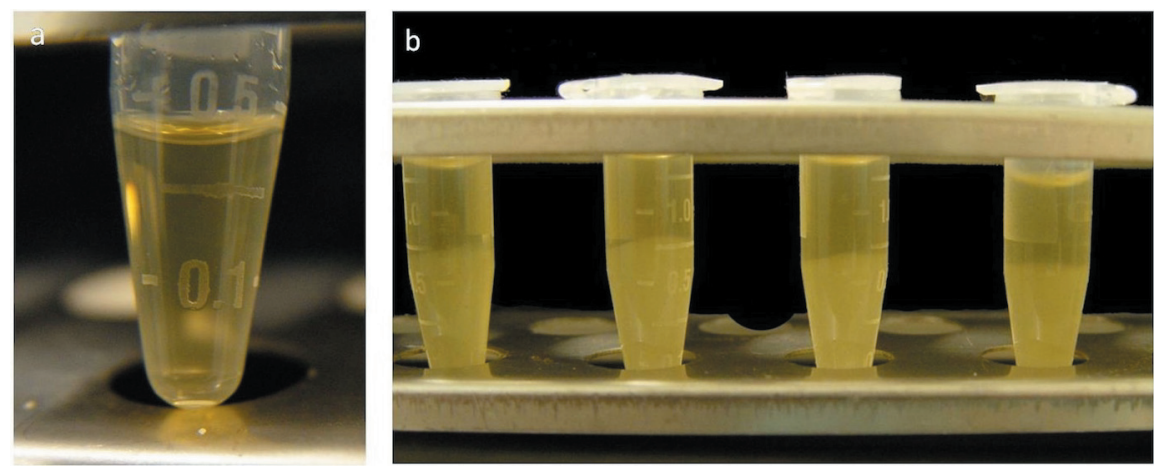

Figure 3- Bacterial viability after 14 days assessed by the turbidity of the brain heart infusion (BHI) broth. A: negative control; B: bacterial growth to confirm viability

bacteria (Figure 3). If the bacteria were not viable after this period, the sample would be excluded to prevent a false negative result.

For the statistical analysis, comparison of microleakage among the groups was performed by the Kruskal-Wallis test. The significance level was set at $p<0.05$.

\section{RESULTS}

\section{First phase}

After $24 \mathrm{~h}$, all of the swabs obtained from the I/A interfaces after abutment installation for groups V1.0 and V1.5 presented bacterial growth, which was assessed by the turbidity of the BHI broth in these swabs. It demonstrated the overflow of the bacterial suspension. Therefore, for the second phase, $0.5 \mu \mathrm{L}$ of bacterial solution was selected for the type of implant that was used in this study.

\section{Second phase}

After $24 \mathrm{~h}$, one of the T20 group samples presented contamination by evaluation of the swab after the abutment installation; thus, it was excluded. During the first $24 \mathrm{~h}$, two samples from group T10 (20\%) and one sample from group T20 (10\%) presented bacterial growth and turbidity of the BHI broth, indicating bacterial microleakage. No samples from the T32 group presented bacterial microleakage. During 14 days, none of the other samples presented signs of bacterial microleakage. No statistically significant differences among the groups were observed $(p<0.05)$. After the 14day period, the I/A samples were opened and the bacterial viability was confirmed in all the samples (Figure 3).

\section{DISCUSSION}

Microleakage at the I/A interface in different implant systems has been evaluated by using methods with bacteria $3,4,7,10,12,16,20,21,23,24,28,30$, their toxins $^{29}$, and even dyes ${ }^{8,13,23}$. However, the results demonstrate great variability, suggesting that some limitations in these designs exist, hindering its reproducibility.

Microbiological studies, in general, are very sensitive due to the handling of biological agents. These biological agents are susceptible to changes in the working and storage environment. It is even more critical when that environment has limitations in terms of the size and source of nutrition and oxygen for the microorganism, as is the case within the implant internal cavity. It is important to adopt procedures to minimize the possibility of operator-related mistakes. It is also vital to establish a methodology that allows reproducible results among different researchers, which makes it possible to compare microleakage at the I/A interfaces of different implant systems ${ }^{29}$. In this study, special care was taken to keep the samples sterile and prevent contamination during inoculation by taking swabs of the external surfaces of each sample throughout the experiment. These procedures could guarantee that the only factor accounting for turbidity of the broth would be related to bacteria migrating from the implant internal cavity.

Some of the studies that evaluate the microleakage at the I/A interface use forceps to hold the implants when inoculating the bacteria and seating the abutments $3,4,9,12,14,16,19,21$. This procedure is frequently carried out with free-hand inoculation of the bacteria $3,4,8,9,12-14,16,19,21,29,30$. The implant internal cavity has a 2-3 mm opening, which is a very tight space that requires a high level of operator precision when inoculating the bacteria. Coming into contact with the implant internal cavity opening could lead to false positive results by facilitating the bacteria's migration to the outside. The use of excessive force with the forceps close to the implant platform could also distort the titanium implant ${ }^{2}$, which increases the gap at the I/A interface and favors bacterial migration. Based on these facts, two devices have been developed for this study. The first is intended to firmly hold the implant at its apical portion and prevent distortion of the coronal aspect. The second is a pipette 
carrier that holds the pipette in a stable position in order to prevent the samples from becoming contaminated (Figure 2).

Because there are several different implant systems, different amounts of bacterial suspension have been used to inoculate the implants in microleakage studies $3,4,9,12,14,16,19-22,29,30$. The amount of material that is added to the implant internal cavity can influence bacterial leakage as it could express during the abutment placement. Therefore, the internal volume must be determined when designing these experiments. To minimize the risk of using excess material, the first step of the study was to evaluate the amount of bacterial suspension that would fit our specific implant design. The analysis of the turbidity of the broth with the cotton swabs from the outer part of the I/A interface after the abutment installation demonstrated bacterial leakage for groups V1.0 and V1.5 after $24 \mathrm{~h}$. Thus, a $0.5-\mu L$-bacterial suspension was used for the second part of this study.

The implants were covered up to the I/A interface $4,9,12,14,16,19,30$ to eliminate the flow of microorganisms at the abutment/screw interface, as has been observed in a previous study ${ }^{24}$, and also to eliminate the use of sealing materials $s^{3,4,19,21,23,30}$. This study used abutments with a $4 \mathrm{~mm}$-high gingival collar to separate the abutment/screw interface from the BHI broth.

The bacterium that was used in this study was E. coli. It is a gram-negative, rod-shaped, facultative anaerobic bacterium that ranges from 1.1 to $1.5 \mu \mathrm{m}$ in diameter and 2 to $6 \mu \mathrm{m}$ in length. It exhibits a high degree of motility ${ }^{16,30}$ and survival in adverse environments. This bacterium was selected because of its ability to survive the study conditions since the implant internal cavity would have a limited supply of oxygen and nutrients for 14 days. In vitro studies that use round bacteria reported that most of the microleakage occurred in the first couple of days $s^{3,12,16,21}$. The same trend was also observed in this study, which could be due to the reduction of the amount of nutrients in the medium. It also suggests that a longer incubation time could lead to the death of the bacteria. After a 14-day follow-up, the bacteria inside the implant internal cavity were proven to be viable and able to expand after $24 \mathrm{~h}$. Some studies that did not check the bacterial viability could obtain misleading conclusions regarding the microleakage at the I/A interface ${ }^{9}$. Microleakage that occurs only during the first couple of days reinforces the hypothesis that the conditions inside the implant's internal cavity become extremely adverse to bacterial survival, growth, and movement through the I/A interface. A control group for this type of study would be a group that would always lead to microleakage even at the $0.5 \mu \mathrm{L}$ volume by keeping a gap at the I/A interface. However, in this study no control group was selected because the idea was to evaluate the microleakage with different amounts of bacterial solution and different tightening torques.

Even though two of the I/A assemblies that were tightened to $10 \mathrm{Ncm}$ and one tightened to 20 $\mathrm{Ncm}$ torque showed bacterial leakage at the I/A interface, a statistical evaluation did not show any difference among the different tightening torque groups. Bacterial leakage was not observed in the $32 \mathrm{Ncm}$ tightening torque group. Within these study conditions, torque tightening did not statistically affect the microleakage at the I/A interface and contrasts with a different study that used dyes ${ }^{13}$. In this study, the $\mathrm{EH}$ connection showed a low incidence of bacterial leakage at the I/A interface, which was also a finding that differed from previous studies $3,10,19,21$.

Based on the recent in vitro bacterial microleakage studies $3,9,19-21$ one limiting factor in this study was the fact that we did not use cyclic loading. Even though there have been indications that with cyclic loading the microgap can increase and facilitate the flow of fluids, primarily in $\mathrm{EH}$ designs $^{27,28,30}$. Harder and cowokers ${ }^{14}$ in 2010 reported that more stable connections, such as a internal conical with a microgap of approximately 2-4 $\mu \mathrm{m}$, could allow the flow of toxins of minute sizes. These toxins come from the bacterial cell wall and are mainly responsible for the bone loss in the area ${ }^{18}$ It suggests that the bone loss is more related to the distance from the interface to the bone ${ }^{17}$ than to the bacterial flow in the area $6,15,16$. This study aimed in calculating the ideal amount of fluids that could be inoculated inside the implant internal cavity without leading to false positive or false negative results. This study also tried to validate a device that could allow adequate inoculation of the material without contaminating the external surface of the implant and abutment. Despite that, the results of this study indicate that in static conditions, implants with a $32 \mathrm{Ncm}$ tightening torque do not allow bacterial microleakage at the I/A interface.

In vitro studies with microorganisms have some difficulties that are related to handling, due to the size of the implants and the challenge in maintaining sterile conditions throughout the experiment. It is also difficult to measure the amount of leakage that is detected at the interface and to conduct long-term experiments with viable amounts of bacteria. Nevertheless, additional studies should be conducted to evaluate the bacterial microleakage as well as that of its toxins. These experiments should be conducted in different implant systems and in different loading conditions to better evaluate the importance of the microgap on bacterial microleakage. 
The present study reinforces the importance of using different amounts of bacterial suspension for different implant systems, procedures for handling the implants and inoculating the bacteria, and also to check for the overflow of bacterial suspension and viability. Since this study did not use dyes that contain particles of approximately the same size as bacterial toxins and are related to bone loss, or cyclic loading, which can interfere with microleakage, it is imperative to conduct additional studies to address these issues.

\section{CONCLUSION}

Within the limitations of this study, it was concluded that the tightening torque did not statistically influence bacterial microleakage at the I/A interface of EH implants. Nonetheless, only the samples that were tightened to $32 \mathrm{Ncm}$ failed to present any sign of bacterial contamination in static conditions. After 14 days, the bacteria in the internal cavity of the implant were proven to be viable. Regarding the amount of bacterial suspension that should be added to the implant internal cavity, this study found that $0.5 \mu \mathrm{L}$ is the ideal amount to prevent overflow and cause false positive results. Although the in vitro methodology to evaluate bacterial microleakage in implants is efficient, it has some limitations, and operatordependent variables should be minimized.

\section{ACKNOWLEDGMENTS}

The authors would like to thank Neodent Implante Osteointegrável for the donation of the implants and abutments, the Microbiology Laboratory of the Technical School of Health Federal University of Uberlândia and Prof. Carlos José Soares and Prof. Gustavo Mendonça for helping with this manuscript.

\section{REFERENCES}

1- Albrektsson T, Zarb G., Worthington P, Eriksson AR. The long-term efficiency of currently used dental implants: a review and proposed criteria of success. Int J Oral Maxillofac Implants. 1986;1:11-25.

2- American Society for Testing and Materials (ASTM). Standard specification for unalloyed titanium for surgical implant applications. In: Annual book of ASTM standards. Medical devices and services. Pennsylvania: ASTM: 1997. v. 13.01:1-3. Designation: F 67-95.

3- Barbosa RE, Nascimento C, Issa JP, Watanabe E, Ito IY, Albuquerque RF Jr. Bacterial culture and DNA Checkerboard for the detection of internal contamination in dental implants. J Prosthodont. 2009;18:376-81.

4- Besimo CE, Guindy JS, Lewetag D, Meyer J. Prevention of bacterial leakage into and from prefabricated screw-retained crowns on implants in vitro. Int J Oral Maxillofac Implants 1999; 14:654-60.
5- Broggini N, McManus LM, Hermann JS, Medina R, Schenk RK, Buser $D$, et al. Peri-implant inflammation defined by the implantabutment interface. J Dent Res. 2006;85:473-8.

6- Broggini N, McManus LM, Hermann JS; Medina RU, Oates TW, Schenk RK, et al. Persistent acute inflammation at the implantabutment interface. J Dent Res. 2003;82:232-7.

7- Byrne D, Houston F, Cleary R, Claffey N. The fit of cast and premachined implant abutments. J Prosthet Dent. 199;80:184-92. 8- Coelho PG, Sudack P, Suzuki M, Kurtz KS, Romanos GE, Silva NR. In vitro evaluation of the implant abutment connection sealing capability of different implant systems. J Oral Rehabil. 2008;35:917-24.

9- Dibart S, Warbington M, Su MF, Skobe Z. In vitro evaluation of the implant-abutment bacterial seal: the locking taper system. Int J Oral Maxillofac Implants. 2005;20:732-7.

10- Duarte AR, Rossetti PH, Rossetti LM, Torres SA, Bonachela WC. In vitro sealing ability of two materials at five different implantabutment surfaces. J Periodontol. 2006;77:1828-32.

11- Goodacre CJ, Bernal G, Rungcharassaeng K, Kan JY. Clinical complications with implants and implant prostheses. J Prosthet Dent. 2003;90:121-32.

12- Guindy JS, Besimo CE, Besimo R, Schiel H, Meyer J. Bacterial leakage into and from prefabricated screw-retained implant-borne crowns in vitro. J Oral Rehabil. 1998;25:403-8.

13- Gross M, Abramovich I, Weiss EI. Microleakage at the abutment-implant interface of osseointegrated implants: a comparative study. Int J Oral Maxillofac Implants. 1999;14:94100.

14- Harder S, Dimaczek B, Açil Y, Terheyden H, Freitag-Wolf S, Kern M. Molecular leakage at implant-abutment connection - in vitro investigation of tightness of internal conical implant-abutment connections against endotoxin penetration. Clin Oral Investig. 2010;14:427-32.

15- Hermann JS, Buser D, Schenk RK, Cochran DL. Crestal bone changes around titanium implants. A histometric evaluation of unloaded non-submerged and submerged implants in the canine mandible. J Periodontol. 2000;71:1412-24.

16- Jansen VK, Conrads G, Richter EJ. Microbial leakage and marginal fit of the implant-abutment interface. Int J Oral Maxillofac Implants. 1997;12:527-40.

17- Lazzara RJ, Porter SS. Platform switching: a new concept in implant dentistry for controlling post-restorative crestal bone levels. Int J Periodontics Restorative Dent. 2006,26:9-17.

18- Nair SP, Meghji S, Wilson M, Reddi K, White P, Henderson B. Bacterially induced bone destruction: mechanisms and misconceptions. Infect Immun. 1996;64:2371-80.

19- Nascimento C, Barbosa RE, Issa JP, Watanabe E, Ito IY, Albuquerque RF Jr. Bacterial leakage along the implant-abutment interface of pre-machined or cast components. Int J Oral Maxillofac Surg. 2008;37:177-80.

20- Nascimento C, Barbosa RE, Issa JP, Watanabe E, Ito IY, Albuquerque RF Jr. Use of checkerboard DNA-DNA hybridization to evaluate the internal contamination of dental implants and comparison of bacterial leakage with cast or pre-machined abutments. Clin Oral Implants Res. 2009;20:571-7.

21- Nascimento C, Pedrazzi V, Miani PK, Moreira LD, Albuquerque Junior RF. Influence of repeated screw tightening on bacterial leakage along the implant-abutment interface. Clin Oral Implants Res. 2009;20:1394-7.

22- Paolantonio M, Perinetti G, D'Ercole S, Graziani F, Catamo G, Sammartino $G$, et al. Internal decontamination of dental implants: an in vivo randomized microbiologic 6-month trial on the effects of a chlorhexidine gel. J Periodontol. 2008;79:1419-25.

23- Piattelli A, Scarano A, Paolantonio M, Assenza B, Leghissa GC, Di Bonaventura $G$, et al: Fluids and microbial penetration in the internal part of cement-retained versus screw-retained implantabutment connections. J Periodontol. 2001;72:1146-50. 
24- Quirynen $M$, Bollen $C M$, Eyssen $H$, van Steenberghe $D$. Microbial penetration along the implant components of the Brånemark system. An in vitro study. Clin Oral Implants Res. 1994;5:239-44.

25- Ribeiro CG, Maia ML, Scherrer SS, Cardoso AC, Wiskott HW. Resistance of three implant-abutment interfaces to fatigue testing. J Appl Oral Sci. 2011;19:413-20.

26- Ricomini AP Filho, Fernandes FS, Straioto FG, da Silva WJ, Del Bel Cury AA. Preload loss and bacterial penetration on different implant-abutment connection systems. Braz Dent J. 2010;21:123-9.

27- Rimondini L, Marin C, Brunella F, Fini M. Internal contamination of a 2-component implant system after occlusal loading and provisionally luted reconstruction with or without a washer device. J Periodontol. 2001;72:1652-7.
28- Scarano A, Assenza B, Piattelli M, Iezzi G, Leghissa GC, Quaranta A, et al. A 16-year study of the microgap between 272 human titanium implants and their abutments. J Oral Implantol. 2005;31:269-75.

29- Silva-Neto JP, Nobilo MA, Penatti MP, Simamoto PC Jr, Neves FD. Influence of methodologic aspects on the results of implantabutment interface microleakage tests: a critical review of in vitro studies. Int J Oral Maxillofac Implants. 2012;27:793-800.

30- Steinebrunner L, Wolfart S, Bössmann K, Kern M. In vitro evaluation of bacterial leakage along the implant-abutment interface of different implant systems. Int J Oral Maxillofac Implants. 2005;20:875-81. 